\title{
Integrating Corporate Social Responsibility and Corporate Governance at the Company Level. Towards a Conceptual Model
}

\author{
Maria Aluchna, Maria Roszkowska-Menkes
}

Warsaw School of Economics

Niepodleglosci al.162 02-554 Warsaw, Poland

E-mail.maria.aluchna@sgh.waw.pl,maria.roszkowska-menkes@sgh.waw.pl

cross $^{\text {ref }}$ http://dx.doi.org/10.5755/j01.ee.30.1.14306

Over the last decade, the strategic implications of corporate social responsibility (CSR) have become one of the most important themes of research in the literature of business in society. While the understanding of a company has been placed for years within the presumed conflict between shareholder and stakeholder, today the shift towards an integrated approach is expected by various constituencies and driven by regulation. Thus, corporate governance (CG) focusing solely on financial performance cannot be an asset for companies if detached from the assumptions of socially and environmentally responsible business. CSR isolated from strategy and governance does not provide the fundamental change towards integrated thinking and a transition to a low-emission, resource-efficient economy.

This article is based on a systematic literature review addressing links between corporate governance and CSR at the company level. We indicate a radical reorientation in both concepts and reveal the corresponding evolution of the theoretical view developing from agency theory towards enlightened shareholder value and a stakeholder-agency view. Specifically, adopting two dimensions of strategic fit between CSR activity and the core business and formal environmental, social, and governance (ESG) compliance, we propose a four-mode integration construct of a corporate social responsibility and corporate governance $(C S R-C G)$ relationship. We identify actions undertaken by a company in the selected modes with respect to strategic focus, supervision, accountability, performance measures, and reporting.

Keywords: Corporate Social Responsibility; Corporate Governance; CSR and Corporate Governance Integration; CSR Strategies.

\section{Introduction}

Companies' ability to grow and continuously develop is determined by its social competences, ethical responsibility, and environmental contributions (Hardjono, 2001). Corporate social responsibility (CSR) and corporate governance (CG) focus on similar dimensions of a firm's operation. However, both concepts have been developing separately (Bhimani \& Soonawalla, 2005), proposing competitive views on how business should be done and what goals should be achieved. The review of the existing literature indicates that both concepts are still far from providing answers to these questions; however, after years of conflicting approaches, it is possible to identify mutual links and synergies and offer a broader, more holistic view on companies (Beltratti, 2005; Jamali et al., 2008; Kolk \& Pinkse, 2010; Jo \& Harjoto, 2011; Salciuviene et al., 2016). The research problem in this article refers to the identification of the relationship and synergies between CSR and $\mathrm{CG}$ at the company level.

A growing number of authors, turning to the origins of the stakeholder theory that, as Freeman $(1999 ; 2010)$ states, are instrumental, currently call for the strategic approach to CSR, defined as a concept of understanding the relations between business and society. According to CSR principles, social, ethical, and environmental aspects are integrated into corporate strategies on a voluntary basis and in cooperation with stakeholders. CSR offers a multi-dimensional view on corporate performance, including financial, social, and environmental components that lead to the creation of shared value (Porter \& Kramer, 2011) for shareholders and stakeholders. CSR also identifies, prevents, and mitigates possible adverse impacts of business (COM, 2011). It may serve as a source of innovation or a competitive advantage, become an element of corporate governance, and contribute to firm value expected by shareholders.

CG is generally understood as a system by which organisations are directed and controlled and which determines the distribution of rights and responsibilities among shareholders and managers, decision-making rules and procedures (Tricker, 2012). In the broader context, CG indicates who governs the company, specifically, who and how decides about its investment, development, expansion, and profit distribution (Mallin, 2004). It also represents the division of power in the company and in the society, indicating the purpose of the corporation and, as a consequence, the prevalent model of doing business. CG focuses on protecting investor rights, increasing transparency, improving financial performance, and maximizing shareholder value (Vogel, 2005; Dore, 2008). Dividend payouts and sufficient return on investment are seen as the main goals of the firm and the measures for assessing the performance of executives.

As Elkington (2006:522) underlines, “it's timely to review the increasingly complex cross-connects between the rapidly mutating governance agenda and the burgeoning world of corporate responsibility, social entrepreneurship, and sustainable development". In addressing this call, the 
authors have presented various approaches. First of all, some studies concentrate on explaining the influence of different national CG regimes on companies' CSR practices (Aguilera et al., 2006; Jackson \& Apostolakou, 2009; Prior et al., 2008). Secondly, there is a number of research papers on the influence of governance on corporate attention to stakeholders addressing a single governance mechanism, such as ownership structure (i.e., insider ownership, institutional ownership, pension and investment fund ownership, government ownership) (Barnea \& Rubin, 2010; Graves \& Waddock, 1994; Johnson \& Greening, 1999; Prado-Lorenzo et al., 2009; Zahra et al., 1993), board structure (in particular, the proportion of outsiders on the board) (Ayuso \& Argandona, 2007; Coffey \& Wang, 1998), compensation politics (Mahoney \& Thorne, 2005) or takeover protection (Kacperczyk, 2009). Finally, some studies focus on explaining how CSR relates to good (or poor) CG in general (i.e., understood as a particular set of mechanisms) and the company's performance (Harjoto \& Jo, 2011; Jamali et al., 2008; Jo \& Harjoto, 2011).

The relevance of this paper refers to the call by Elkington (2006) and addresses the discussion carried out in the existing literature (Jamali et al., 2008; Kolk \& Pinkse, 2010; Moon et al., 2010; Valackiene \& Miceviciene, 2011; (Harjoto \& Jo, 2011) on the evolution of CSR (e.g., sharedvalue approach, benefit-corporation concept) and the development of corporate governance (e.g., enlightened corporate governance, responsible corporate governance).

The objective of the article is to review the results of existing studies and trace the modes of CSR and CG integration at the company level. We review the literature to examine the financial performance of responsible companies (impact of CSR/sustainability strategies), search for companies' characteristics or institutional determinants that drive the adoption of CSR, and identify the interactions between CG and CSR standards and practice.

In addressing the objective of the study, we contribute to the existing literature in three ways. First, we offer an extensive systematic synthesis and review of the relevant literature tracing the relationships between CG and CSR. We indicate a radical reorientation in both concepts. CSR initiatives advance from philanthropic programmes to authentic strategies intended to regain the trust of society at large and generate social change while simultaneously creating value for shareholders. CG development calls for greater accountability and extended fiduciary duty (Sacconi, 2006) with the respective change in supervision and monitoring functions (Kurland, 2017).

Second, in analysing the existing literature, we reveal the corresponding evolution of the theoretical view of links between CG and CSR as developed from agency theory, towards enlightened shareholder value, and leading to a stakeholder-agency view.

Our third contribution derives from the proposed fourmode framework, which mirrors the ongoing debate both in theoretical and empirical studies illustrating modes of correlation between CG and CSR. Specifically, we adopt two dimensions, including, first, the strategic fit between CSR activity and the core business strategy, and, second, compliance with formal guidelines on disclosure. We offer a four-mode CSR-CG integration framework and identify actions undertaken by a company in the selected modes with respect to strategic focus, supervision, accountability, performance measures, and reporting.

Our findings indicate the dominance of two approaches that either perceive CSR and CG antagonistically or view CSR as a shareholder-value-maximisation strategy (enlightened shareholder-value approach). The mode of integration and internalisation of CSR and CG remain on the outskirts of the existing literature.

\section{Research Method}

To identify the relevant research for the analysis, we used systematic review methodology. While selecting the method, we consulted the methodology presented in Tranfield et al. (2003).

The search was conducted within the Web of Science for publications that had "corporate social responsibility" and "corporate governance" in the topic field. The topic field includes the title, keywords, and abstract in the database. The chosen database is generally considered the most comprehensive for scholarly work, includes the most prominent journals in the field (Dahlander \& Gann, 2010), and enables the identification of the most influential and recognised studies. The search was conducted on January 10, 2018. It included articles, abstracts, editorials, book chapters, interviews, and reviews.

The search yielded 552 articles that served as the basis for a bibliometric analysis in order to investigate the growth, scope, and breadth of research combining "corporate social responsibility" and "corporate governance". For decades, both concepts have been developing separately and it was not until 2015 when the link between them started to be intensively explored by scholars. While in 2001 there was only one paper in this field published, between 2015 and 2017, nearly 300 such articles appeared in the most prominent scientific journals. The topic has been discussed in some of the leading peer-reviewed journals, just to name a few: Journal of Business Ethics, Corporate Governance: An International Review, Corporate Social Responsibility and Environment, Journal of Banking \& Finance, Academy of Management Review, and Strategic Management Journal.

The next step focused on the identification of the most influential studies in the area. Then, 50 articles with the largest number of citations were selected from the final list to serve as the basis for a thorough review of the literature on the CSR-CG link. This approach is often used in management literature to offer a conceptual framework of insufficiently explored themes (Juscius \& Jonikas, 2013). It allows the identification of the mainstream studies in a given field. However, such citation counts are biased towards earlier publications and cannot identify more recent work that will be influential in the future, which we acknowledge to be the main limitation of our study.

\section{Origin and Evolution of CSR and CG}

CSR and CG are discussed in a substantial number of studies in management literature (Salciuviene et al., 2016). These concepts offer an understanding of the role of business in society and economy developing at the macro, meso, and micro levels. In the broader (macro) sense, CSR and $\mathrm{CG}$ are outcomes of the balance between the political 
power of interest groups, dominant social norms, and cultural patterns of socialising (Harjoto \& Jo, 2011; Jo \& Harjoto, 2011). The context of institutional and regulatory (meso) environments indicates how CSR and CG are formally incorporated into the existing laws, codes of conduct, and best practice (Mayer, 2012; Jamali et al., 2008). Finally, at the (micro) company level, CSR and CG provide practical solutions such as structures and procedures regulating the functioning of corporate bodies (board of directors, annual shareholder meetings), empowering stakeholders and shareholders in decisionmaking and providing standards for disclosure (financial and non-financial reporting) (Beltratti, 2005).

The basic questions at the heart of CSR, relating to the primary purpose of a firm and its role in the society, are as old as business itself but still raise a lot of controversy. The origins of the research in this area date back at least to the 1950s (Carroll, 1999). According to some of the first conceptualisations, CSR was seen as a framework encompassing a firm's consideration of its economic responsibility to investors and consumers, legal responsibility to the government or the law, ethical responsibilities to society, and discretionary (philanthropic) responsibility to the community (Carroll, 1979). It incorporated the interaction between the principles of social responsibility, the process of social responsiveness, and the policies and programmes designed by corporations to address social issues (Carroll, 1979; Wood, 1991). However, it was not until the 1990s when the field started to be intensively explored. The literature concerning CSR is strongly atomised and does not allow the formation of any coherent theory. Lockett et al. (2006) describe CSR as knowledge in a continuing state of emergence. It cannot be characterised by any dominant paradigm, universal assumptions, or methods. There is no consensus among researchers regarding the definition of CSR, its basic principles, scope (van Marrewijk, 2003; McWilliams et al., 2006), theory of origin (Frynas \& Yamahaki, 2016) and, finally, whether firms have any other social responsibility than to maximise value for their shareholders (Friedman, 1970; Karnani, 2011).

An in-depth content analysis of 37 CSR definitions published between 1980 and 2003 (majority after 1998) identifies five basic dimensions of CSR (Dahlsrud, 2008): economic, social, environmental, voluntariness, and stakeholder. Recently, CSR has been viewed as a concept whereby companies voluntarily integrate social, ethical, and environmental concerns into their business operations and core strategy in close cooperation with their stakeholders. It aims at maximising the creation of shared value (Porter \& Kramer, 2011; Matuleviciene \& Stravinskiene, 2016) for owners/shareholders and for other stakeholders and society at large, as well as identifying, preventing, and mitigating their possible adverse impacts (COM, 2011). It is based on the traditional assumptions of CSR (Carroll, 1979; Wood, 1991) and on the proposals put forward by the authors of alternative approaches such as corporate sustainability (Marrewijk, 2003), triple bottom line (Elkington, 1997), corporate citizenship (Matten et al., 2003) and shared value (Porter \& Kramer, 2011). In this context, CSR is understood as a business contribution to sustainable development (Marrewijk, 2003).
CG has been studied from different perspectives that offer alternative definitions, yet the understanding of what it is appears to be more consistent compared to CSR. Traditionally, CG has been defined as a set of constraints managers impose on themselves or which investors put on managers to reduce the misallocation of profits and encourage investors to provide more funds ex ante (Shleifer \& Vishny, 1997) or as a framework of constraints that determines the ex-post distribution of wealth (Zingales, 2008). As compared to CSR, CG remains more operational and formal in its nature involving organisational decisions made at the senior level that directly influence the incentives, motivations, and behaviour of all employees, and which cascades through an organisation (Larcker \& Tayan, 2013).

CG has been focused on shareholder interest rooted in the paradigm of maximising shareholder value embedded in the principal-agent theory and the financial model of the company (Vogel, 2005; Dore, 2008). These perspectives view profit generation and increasing firm value for shareholders as the main purpose of the firm. The conflicts emphasized by the principal-agent theory (Jensen \& Meckling, 1976) identify governance problems of the separation of ownership and control, giving rise to the managerialist premise. In recent years, the understanding of the goals and functions of $\mathrm{CG}$ has been redirected towards a balance between the interests of various groups and the extended time horizon of the company's operation (Mayer, 2012). Thus, CG should serve as a platform for cooperation between different stakeholders and involving a set of relationships between a company's management, its board, its shareholders, and other stakeholders. It "provides the structure through which the objectives of the company are set, and the means of attaining those objectives and monitoring performance are determined" (G20/OECD 2015, p.9).

\section{Integrating CSR and CG, the Conceptual Model}

The existing literature attempts to track the patterns of the mutual relations between CG and CSR (Huang, 2010). Following the approach of a critical deductive analysis offering a synthesizing approach to management and governance (Baumgartner, 2013) we conducted a systematic review of theoretical and empirical studies on the interrelations, links, and interdependencies between CSR and CG, analysing the 50 most cited articles as categorised by Web of Science (Appendix 1). The reviewed articles examine the financial performance of responsible companies (impact of CSR/ sustainability strategies), seek out the companies' characteristics or institutional determinants that drive the adoption of CSR, and identify the interactions between CG and CSR standards and practice. The literature referring both to theoretical discussions and empirical analyses has been evolving, however, not linearly, developing both concepts and revealing different modes of correlation between $\mathrm{CG}$ and CSR.

The synthesis of the reviewed empirical and theoretical studies can be structured in the four-mode integration of CSR and CG. The model uses two dimensions of strategic fit understood as the relations of 
Maria Aluchna, Maria Roszkowska-Menkes. Integrating Corporate Social Responsibility and Corporate Governance...

CSR activity to the core business strategy and formal compliance, for example, in the adoption of formal guidelines on reporting and transparency standards. As shown in Table 1, we distinguish: antagonism, instrumental legitimacy, instrumental strategy, and, finally, integration and internalisation. The modes do not represent a linear process of the development of a company approach to CSR and CG, rather they document various options of the strategic alliance of these two concepts as found in the theoretical as well as empirical studies.

Description of Corporate Social Responsibility (CSR) and Corporate Governance (CG) Integration Modes

\begin{tabular}{|c|c|c|c|}
\hline & Corporate social responsibility (CSR) & Corporate governance (CG) & $\begin{array}{l}\text { Representative references } \\
\text { (in alphabetical order) }\end{array}$ \\
\hline \multicolumn{4}{|c|}{ Antagonism } \\
\hline $\begin{array}{l}\text { General } \\
\text { description }\end{array}$ & $\begin{array}{l}\text { Altruistic CSR = CSR over-investment } \\
\text { Negative CSR } \\
\text { CSR not tied to business goals }\end{array}$ & $\begin{array}{l}\text { Maximizing shareholder value, investment } \\
\text { in social and environmental activity seen } \\
\text { as a cost }\end{array}$ & \multirow{6}{*}{$\begin{array}{l}\text { Arenas et al. (2004); Arora \& } \\
\text { Dharwadkar (2011), Barnea \& } \\
\text { Rubin (2010), Bondy et al. (2008), } \\
\text { Chih et al. (2008), Dam \& } \\
\text { Scholtens (2012), Fisher-Vanden } \\
\& \text { Thorburn (2011), Galema et al. } \\
\text { (2008), Guay et al. (2004), Heath } \\
\& \text { Norman (2004), Lantos (2002), } \\
\text { Levy et al. (2010), Li \& Zhang } \\
\text { (2010), Mahoney \& Thorne } \\
\text { (2005), Prior (2008), Renneboog et } \\
\text { al. (2008) }\end{array}$} \\
\hline $\begin{array}{l}\text { Strategic/ } \\
\text { executive focus }\end{array}$ & $\begin{array}{l}\text { None } \\
\text { Avoiding fines }\end{array}$ & Financial goals & \\
\hline $\begin{array}{l}\text { Board/ supervision } \\
\text { focus }\end{array}$ & Ignorance & Creating firm value & \\
\hline Accountability & $\begin{array}{l}\text { Limited towards entities, not linked to } \\
\text { strategy }\end{array}$ & $\begin{array}{l}\text { Towards shareholders, based on fiduciary } \\
\text { duty }\end{array}$ & \\
\hline $\begin{array}{l}\text { Performance } \\
\text { evaluation }\end{array}$ & $\begin{array}{l}\text { Measuring the social benefits from } \\
\text { altruistic CSR } \\
\text { Financial costs of negative CSR }\end{array}$ & $\begin{array}{l}\text { Based on accounting and stock market } \\
\text { measures }\end{array}$ & \\
\hline Reporting & Incidental news & Financial reports & \\
\hline \multicolumn{4}{|c|}{ Instrumental legitimacy } \\
\hline $\begin{array}{l}\text { General } \\
\text { description }\end{array}$ & $\begin{array}{l}\text { CSR activity driven by legitimacy and } \\
\text { reputation }\end{array}$ & $\begin{array}{l}\text { Social and environmental performance } \\
\text { seen as a driver for financial performance }\end{array}$ & \multirow{6}{*}{$\begin{array}{l}\text { Aguilera et al. (2007), Garcia- } \\
\text { Sanchez et al. (2013), Gordon } \\
\text { (2007), Jackson \& Apostolakou } \\
\text { (2010), Jamali et al. (2008), Khan } \\
\text { et al. (2013), Lattemann et al. } \\
\text { (2009), Shamir (2004), Sobhani et } \\
\text { al. (2009) }\end{array}$} \\
\hline $\begin{array}{l}\text { Strategic/ } \\
\text { executive focus }\end{array}$ & $\begin{array}{l}\text { Linked to business operations, attaining } \\
\text { legitimacy, improving reputation }\end{array}$ & Financial goals & \\
\hline $\begin{array}{l}\text { Board/ supervision } \\
\text { focus }\end{array}$ & $\begin{array}{l}\text { Limited, balancing a firm's negative } \\
\text { impact on society and the environment }\end{array}$ & Creating firm value & \\
\hline Accountability & Towards stakeholders & $\begin{array}{l}\text { Towards shareholder, based on fiduciary } \\
\text { duty }\end{array}$ & \\
\hline $\begin{array}{l}\text { Performance } \\
\text { evaluation }\end{array}$ & Related to CSR/environmental measures & $\begin{array}{l}\text { Based on accounting and stock market } \\
\text { measures }\end{array}$ & \\
\hline Reporting & CSR disclosure & Financial reports & \\
\hline \multicolumn{4}{|c|}{ Instrumental strategy } \\
\hline $\begin{array}{l}\text { General } \\
\text { description }\end{array}$ & $\begin{array}{l}\text { CSR closely related to corporate strategy, } \\
\text { supporting achievement of business goals }\end{array}$ & $\begin{array}{l}\text { Governance assuring strategic orientation } \\
\text { of CSR efforts }\end{array}$ & \multirow{6}{*}{$\begin{array}{l}\text { Aguilera et al. (2006), Aguilera et } \\
\text { al. (2007), Aguinis \& Glavas } \\
\text { (2013), Ammann et al. (2011), } \\
\text { Harjoto \& jo (2011), Freeman \& } \\
\text { Hasnaoui (2011), Harjoto \& jo } \\
\text { (2012), Jackson \& Apostolakou } \\
\text { (2010), Jo \& Harjoto (2011), } \\
\text { Kacperczyk (2009), Kang \& Moon } \\
\text { (2012), Lantos (2002), Lo \& Sheu } \\
\text { (2007), Michelon et al. (2013), } \\
\text { Prado-Lorenzo et al. (2009) }\end{array}$} \\
\hline $\begin{array}{l}\text { Strategic/ } \\
\text { executive focus }\end{array}$ & Creating shared value & $\begin{array}{l}\text { Creating shared value, CSR/sustainable } \\
\text { development }(\mathrm{SD}) \text { with impact on firm } \\
\text { value/ performance }\end{array}$ & \\
\hline $\begin{array}{l}\text { Board/ supervision } \\
\text { focus }\end{array}$ & $\begin{array}{l}\text { Compliance with environmental, social } \\
\text { and governance (ESG) criteria }\end{array}$ & $\begin{array}{l}\text { Compliance, incorporating ESG criteria } \\
\text { into the formal evaluation of executives }\end{array}$ & \\
\hline Accountability & Towards stakeholders & $\begin{array}{l}\text { Towards shareholders, based on fiduciary } \\
\text { duty }\end{array}$ & \\
\hline $\begin{array}{l}\text { Performance } \\
\text { evaluation }\end{array}$ & $\begin{array}{l}\text { International Integrated Reporting } \\
\text { Council (IIRC) standards, Global } \\
\text { Reporting Initiative ( GRI) standards }\end{array}$ & $\begin{array}{l}\text { Based on accounting and stock market } \\
\text { measures }\end{array}$ & \\
\hline Reporting & CSR disclosure, combined reports & Financial reports, combined reports & \\
\hline \multicolumn{4}{|c|}{$\begin{array}{c}\text { Integration and internalization } \\
\end{array}$} \\
\hline $\begin{array}{l}\text { General } \\
\text { description }\end{array}$ & $\begin{array}{l}\text { CSR integrated with corporate strategy } \\
\text { and business model } \\
\text { Economic, social, and environmental } \\
\text { goals mutually reinforcing }\end{array}$ & $\begin{array}{l}\text { Governance balancing social, } \\
\text { environmental, and financial performance }\end{array}$ & \multirow{6}{*}{$\begin{array}{l}\text { Brammer et al. (2012), Fassin } \\
\text { (2005, 2012), Fassin et al. (2011), } \\
\text { Frynas (2008), Sacconi (2006), } \\
\text { Whelan (2012) }\end{array}$} \\
\hline $\begin{array}{l}\text { Strategic/ } \\
\text { executive focus }\end{array}$ & Creating stakeholder value & Creating stakeholder value & \\
\hline $\begin{array}{l}\text { Board/ supervision } \\
\text { focus }\end{array}$ & $\begin{array}{l}\text { Compliance, balancing ESG criteria to } \\
\text { strategic review and formal evaluation of } \\
\text { executives }\end{array}$ & $\begin{array}{l}\text { Compliance, balancing ESG criteria to } \\
\text { strategic review and formal evaluation of } \\
\text { executives }\end{array}$ & \\
\hline Accountability & Towards stakeholders & $\begin{array}{l}\text { Towards stakeholders, based on multi- } \\
\text { fiduciary duty }\end{array}$ & \\
\hline $\begin{array}{l}\text { Performance } \\
\text { evaluation }\end{array}$ & $\begin{array}{l}\text { Based on social, economic and } \\
\text { environmental performance (tri-profit) }\end{array}$ & $\begin{array}{l}\text { Based on social, economic, and } \\
\text { environmental performance (tri-profit) }\end{array}$ & \\
\hline Reporting & Integrated reports & Integrated reports & \\
\hline
\end{tabular}

\section{Antagonism}

Antagonism mode is characterized by the conflict between CSR and CG, revealing the contradiction in the fundamental assumptions of these two concepts. In this research stream, CSR is defined within an altruistic approach as "situations where the firm goes beyond compliance and engages in actions that appear to further some social good, beyond the interests of the firm and that which is required by law" (McWilliams et al., 2006:1). The altruistic approach represents fulfilment of an 
organisation's philanthropic responsibilities, surpassing the prevention of possible harm, regardless of whether or not this will benefit the business itself (Lantos, 2002). Freeman and McVea (2001) note that the separation of social and environmental corporate activities from the core strategy 'has resulted in CSR being seen as 'add-on' luxury that can be only afforded by the most successful businesses, or as a damage limitation insurance, rather than as a core element of the business strategy."

$\mathrm{CG}$ in antagonism mode follows the underlying idea that the "business of business is business", emphasizing the shareholder imperative and focus on maximising firm value (Dore, 2008). Shareholders are tied to a company with a special relationship that does not promise anything, since the contract does not provide any guarantee of a return on their investment or profit distribution. Shareholder primacy driven by fiduciary duty stipulates that the board of directors is legally obliged to maximise shareholder value (Vermalen, 2009). As a result, valuebased management dominates while investment in social and environmental activity are seen as unnecessary costs.

Within this mode, CSR is not tied to business goals or used for improving performance but derives from nonbusiness-related activities (sometimes purely altruistic ones) of managers and owners, leading to CSR overinvestment (Barnea \& Rubin, 2010). For instance, altruistic CSR activities may result from the pressures of shareholder activists, whose mission is to represent the social or environmental interests of various civil-society groups and to stimulate ethical business conduct (Guay et al., 2004). Additionally, Barnea \& Rubin (2010) find that insiders (managers and large blockholders) induce firms to over-invest in CSR for their private benefit since it improves their reputation as being good global citizens. In such cases, CSR is viewed as a result of a conflict between shareholders and an illustration of weak CG structures. In fact, there is empirical evidence that corporate social performance and good corporate performance are uncorrelated (Bondy et al., 2008; Barnea \& Rubin, 2010; Dam \& Scholtens, 2012). Although effective CG mitigates the risk of negative CSR (violation of regulations and standards), it also discourages positive CSR (proactive stakeholder relationship management) (Mahoney \& Thorne, 2005; Arora \& Dharwadkar, 2011). In other words, it promotes the so-called "doing nothing wrong" approach to social and environmental issues while proactive engagement in CSR is perceived as an agency cost. Fisher-Vanden and Thorbur (2011) show that with less shareholder oversight, managers have more discretion to make profound, voluntary environmentally responsible investment, which, perceived as a value-reducing exercise, results in negative abnormal stock returns. If managers try to address the interests of all stakeholders (multiple objectives), instead of pursuing the single objective of value maximisation, they are left unaccountable. They tend to divert the firm's resources to pursue their own interests, which ultimately shows up in the accounting earnings (Chih et al., 2008). Similar results are provided by Prior (2008), who finds that CSR is abused to garner support from stakeholders and, therefore, provides an opportunity for the entrenchment of managers who manipulate earnings.
Since there is no consistent empirical evidence that CSR investment supports a firm's value maximisation (Galema et al., 2008; Renneboog et al., 2008) and companies as well as investors are expressing doubts about the payoff from social performance (Levy et al., 2010), CSR activities are either the result of institutional pressures or an illustration of the agency problem (Renneboog et al., 2008). Thus, as Heath and Norman (2004) argue, a strong commitment to CSR is institutionally not feasible. The history of political interference, in particular the experience of social-democratic governments during the 1960s and 1970s, and their attempts to impose social responsibility upon the managers of nationalised companies (Heath \& Norman, 2004) or more recent evidence from Chinese state-owned companies (Li \& Zhang, 2010) present a number of warnings against the reconciliation of social responsibility with effective $\mathrm{CG}$.

\section{Instrumental Legitimacy}

Instrumental legitimacy mode is characterized by the deliberative alignment of CSR and CG with the assumption of the conducive character of links between social, environmental, and financial performance. CSR is instrumentally adopted in a more proactive way to attain legitimacy amongst different constituencies in order to generate profit and ensure the return on investment for shareholders. Fleming and Jones (2013) argue that what has come to be called CSR has become through positive publicity and goodwill a key marketing and branding tool for most large and medium-sized companies. In many companies, social responsibility is limited to cosmetic actions, the centrepiece of which are often glossy CSR reports (Porter \& Kramer, 2006). CSR activities have been widely used to keep the civil (Fleming \& Jones, 2013) and political (Shamir, 2004) pressure down.

The purpose of the firm is still solely based on the shareholder value paradigm (Charan \& Freeman, 1980). However, since isolating shareholders from other entities proves to be ineffective for wealth creation (Mayer, 2012), the evolution of $\mathrm{CG}$ allows social and environmental efforts to be undertaken by the company.

The CSR activity is no longer viewed as an unnecessary cost breaching the fiduciary duty. On the contrary, acting in the interest of shareholders and striving for long-term survival require satisfying stakeholder expectations.

Companies, for the purpose of building legitimacy within their environments, construct stories about their actions that correspond to social expectations but which are often decoupled from the core business (Meyer \& Rowan, 1977). Aguilera et al. (2007) argues that shareholders and managers may have instrumental and relational motives to push for CSR and that in the AngloAmerican CG model, these motives are related mostly to short-term benefits, in particular reputation and social legitimation.

CSR efforts, including CSR disclosure, may serve as a tool for attaining social fitness. This is particularly true for companies in high-impact industries (Latteman et al., 2009; Jackson and Apostolakou, 2010), in developing countries (Jamali et al., 2008), especially in exportoriented industries (Khan et al., 2013) or operating in 
collectivist and feminist societies where managers must respond to greater social and environmental demands from their stakeholders (Garcia-Sanchez, 2013). What is more, there is empirical evidence from emerging markets that $\mathrm{CG}$ guidelines and attributes such as board independence and the presence of an audit committee play vital roles in ensuring organisational legitimacy through fragmented and separate CSR disclosure (Sobhani et al., 2009; Khan et al., 2013). Gordon (2007) argues that the CSR movement in 1970 was one of the driving forces of the rise of independent directors in the US.

\section{Instrumental Strategy}

Instrumental strategy mode is characterized by the strategic synergistic links between CSR and CG based on the underlying assumption of the interaction of social, environmental, and financial performance. CSR is seen as extending beyond the economic interests, although it aims at their optimisation (Freeman and Hasnaoui, 2011). This mode is derived from the influential theoretical framework offered by stakeholder theory, assuming that managers must formulate and implement strategies that satisfy all stakeholder groups (Freeman \& McVea, 2001). Freeman's stakeholder theory was driven instrumentally to create an alternative approach (to the shareholder model) to strategic management that would help managers deal with the tremendous change going on in the business environment (Freeman et al., 2004). As argued by Lantos (2002), strategic CSR assumes the fulfilment of those philanthropic responsibilities that will benefit the firm. Recently, a growing number of authors convinced that CSR should play a strategic role in business (Husted \& Allen 2007) show that its activity leads to innovation, cost reduction, increased effectiveness, the best employee retention, or increased attractiveness in the eyes of investors (Porter \& Kramer, 2011). Stakeholder management, which is seen by many authors (Dahlsrud, 2008; Marrewijk, 2003) as an essential element of CSR, is a strategic management process, which implies that the interests of key stakeholders should be integrated with the company's basic goals (Freeman \& McVea, 2001; Matuleviciene \& Stravinskiene, 2016). CSR based on stakeholder management and linked to the core business strategy enables firms to develop rare, hard to imitate, and customer valued resources, such as ethical awareness, ability to manage social and environmental issues and relational resources (Husted \& Allen, 2007). Aguinis and Glavas (2013) argue that CSR activities that involve an organisation's core competences and integrate social and environmental issues within a firm's strategy, routines, and operations, affect all employees and allows companies to reach the goal of "doing well by doing good". In this sense, CSR aims to create shared-value, i.e., generating social change and gaining a competitive advantage at the same time (Porter \& Kramer, 2011).

CG evolves towards the instrumental stakeholder approach, shifting its focus to enlightened shareholder value and backing it with CSR reporting (merely combined rather than fully integrated reports). Following the experience of the financial crisis (Krippner, 2005; Dore, 2008; Clarke, 2014), the fundamental assumption of creating shareholder value as the dominant paradigm is questioned. The negative effects of financialisaton such as excessive risk-taking, short termism, and the dominance of financial goals are blamed for causing instability and increasing uncertainty in company operations. What is more, empirical studies provide evidence that when a company pursues CSR initiatives linked to stakeholder preferences and allocates resources to these initiatives in a strategic way, CSR initiatives have a positive effect on the company's performance in terms of both market-based and accounting-based measures (Michelon et al., 2013). Lo and Sheu (2007) find that companies with remarkable corporate sustainability strategies are more likely to be rewarded by investors with a higher valuation on the financial markets. However, the positive valuation effect of sustainability is reinforced by sales growth, which indicates that for some, sceptical investors, good news on sales growth may be proof of the firm's strategic approach to social and environmental issues and encouragement to give it a higher valuation.

Good CG plays a vital role in ensuring that CSR expenditures are profit-oriented and determines the positive valuation effect of CSR (Ammann et al., 2011). Firms with more effective governance are more likely to engage in CSR activities to reduce a conflict of interest between managers and investing and non-investing stakeholders (conflict-resolution hypothesis). CSR utilised as a conflict-resolution mechanism positively influences operating performance and firm value (Harjoto \& Jo, 2011; Jo \& Harjoto, 2011; Harjoto \& Jo, 2012).

On one hand, Aguilera et al. (2006; 2007) point out that it is in the continental and UK corporate governance model that shareholders with a more long-term investment perspective may be interested in CSR efforts compatible with long-term competitiveness and profitability (employee welfare, high-quality products). Such a strategic approach can be driven by mechanisms, like anti-takeover protection, that decrease the pressure on short-term performance (Kacperczyk, 2009), as well as ownership by large shareholders interested in the long-term success of the firms (Prado-Lorenzo et al., 2009). On the other hand, Kang and Moon (2012) argue that to the extent that countries move toward more liberal or shareholderoriented forms of CG, companies are increasingly adopting market-oriented and competitive forms of CSR along Anglo-American lines. This goes in line with the results of empirical research conducted by Jackson and Apostolakou (2010), who find, contrary to the predictions from neoinstitutional theory, CSR is rather a "substitute" not a "mirror" of national business systems. Higher legal protection for investors and low levels of institutional coordination of business-stakeholder relationships drives diffusion of voluntary CSR, perceived as a source of competitive advantage, and CG based on the enlightened shareholder-value perspective.

\section{Integration and Internalisation}

In strategic mode, companies start to engage in social and environmental issues from their existing business, strategy, or product lines and work on making them more responsible (Dyllick \& Muff, 2016). However, the 
underlying objective remains economic, as the company's CSR efforts are to support maximisation of enlightened shareholder value. Strategic CSR is based on a win-win assumption about business-society relations and as such does not provide any guidance for situations where a winwin solution cannot be reached (Frynas, 2008). Given the complexity of social issues that usually involve a number of different stakeholder groups with conflicting interests, strategic CSR concepts only reinforce neo-liberal logic (Crane et al., 2014). This usually leads to rather incremental improvements and does not enforce any radical changes in the company's strategy and business model (Visser, 2012). According to some researchers, organisations will only be sustainable if the dominant neoclassical model of the firm is transformed, rather than supplemented, by social and environmental priorities (Brown \& Dillard, 2014; Thomson, 2015).

There is a growing need for a sustainable business model (SBM), one in which corporate sustainability and responsibility shape the driving force of the firm and its decision-making (Boons \& Ludeke-Freund, 2013), where social, environmental, and business goals are not merely combined, but integrated in the way they are mutually reinforcing. Scholars in the field call for an integrative or systemic approach focusing CSR activities on identifying and tackling the root causes of a company's present unsustainability and irresponsibility, typically through innovating business models, revolutionising processes, products, and services and lobbying for progressive national and international policies (Visser, 2012), but also ethical management confined not only to the large strategic issues but also applied to the small practical matters of everyday business life (Fassin, 2005). Driven by this new logic, companies go beyond creating value for direct stakeholders and minimising the negative impacts of business activities. Strongly sustainable firms start to utilise their core competences and resources to create positive environmental, social (doing good), and economic (doing well) value throughout their value networks, thereby sustaining the possibility that human and other life can flourish (Upward and Jones, 2015). There is a consensus that to find solutions to the most burning social and environmental challenges the preferred mechanism is the generation of innovation connected to new business models (Boons \& Ludeke-Freund, 2013).

CG shifts to this mode for a series of reasons. First, the claim on primacy and the special rights of shareholders is overruled (Mayer, 2012). Companies are viewed as a constellation of cooperative and competitive interests possessing intrinsic value (Donaldson \& Preston, 1995). Stakeholders make firm specific investments, which are efficient in a given organisational context and cannot be easily transferred to another company. Although stakeholders are dependent on the company's performance, they are neither protected by CG reporting nor represented by the board of directors (Mayer, 2012). A similar argument is proposed by team production theory, which questions shareholder primacy and addresses situations in which individuals invest firm-specific resources to produce a non-separable output and "may find it difficult or impossible to draft explicit contracts distributing the output of their joint efforts, and, as an alternative, might prefer to give up control over their enterprise to an independent third party charged with representing the team's interests and allocating rewards among team members" (Blair \& Stout, 1999).

Second, Sacconi (2006) gives a contractual foundation to the concept of CSR, meant as an extended model of the firm's CG, based on the fiduciary duties owed to all the firm's stakeholders. He views a company as "the structure of a multi-stakeholder firm, on the basis of the idea of a constitutional contract, which satisfies basic requirements of impartial justification and accordance with intuitions of social justice" (Sacconi, 2006, p.259). By establishing the basic context of the incompleteness of contracts and abuse of authority, the author analyses how the extended view of CG arises directly from criticism of the contemporary neoinstitutional economic theory of the firm.

Third, as Brammer et al. (2012) argue, corporations are political creations that, in order to facilitate the accumulation of capital, have received limited liability. Thus, it is not simply a matter of how managers are to be made accountable to shareholders as agency theory implies, but a more fundamental issue of what responsibilities society places on the corporation itself in exchange for the legal privilege of limited liability.

In this mode, $\mathrm{CG}$ offers an important role in the process of decision-making for stakeholders (Huang, 2010), identifying them as owners of fiduciary rights, enriching the previous shareholder-focused approach (multi-fiduciary model). The "synthesis of economics and ethics" (Milton, 2010) and the convergence of CG and CSR is mostly driven by the view that a board of directors fulfils fiduciary duties and is responsible to stakeholders for the company's performance (Moon et al., 2010) or, from the perspective of stakeholder reciprocity, stakeowners, understood as the loyal partners, who strive for mutual benefits and deserve a stake in the firm (Fassin, 2012). Therefore, the tasks of companies evolve to formulate multi-dimensional corporate goals, increase the accountability of directors to a larger group of economic actors, and widen the measures of corporate performance (Khan et al., 2013; Rao \& Tilt, 2016).

This mode of CSR-CG can be already observed in small businesses, where owners are the followers of the principle of satisfying behaviour, rather than the maximisation principle of the homo economicus approach. Shareholder value, CSR, and ethics-related concepts are not mutually exclusive, but rather mutually reinforcing (Fassin et al., 2011). Other examples of CSR and CG integration are benefit corporations, social-purpose corporations, public-benefit corporations, or alternative ownership, such as cooperatives (Bocken et al., 2014). These new legal forms, known as impact-driven firms, redefine the purpose of the business, balancing economic, environmental, and social goals, restructure the understanding of accountability towards stakeholders, and redevelop the responsibilities of governance and supervision (Kurland, 2017). Although there is an increasing number of businesses implementing the systemic approach to CSR and innovating their business models in a radical manner, they are often small-scale, niche initiatives. Whelan (2012) argues that the majority of corporations still engage in CSR for instrumental 
reasons and a $\mathrm{CG}$ model that provides stakeholders with similar voting rights to those that shareholders enjoy is unlikely, at least to be widely endorsed due to concerns regarding self-dealing, functional differentiation, efficiency, and capital supply. Another barrier to the integration of social and environmental concerns in business activity and $\mathrm{CG}$ are the deep-seated misunderstandings and mistrust among various stakeholder groups (Arenas et al., 2009).

As shown in Table 1, the CSR/CG integration mode redevelops a company's management and governance practice. In general, the integration of CSR and CG changes its nature from financial to balanced and increases the time horizon of strategic goals, which translates into considering the impact on society and the environment. The identified CSR impact on governance and management relates in a great sense to the works (Blair \& Stout, 1999; Kolk \& Pinkse, 2010; Mayer, 2012) suggesting the need to include social responsibility in the CG agenda to address the deficiencies of short-term thinking, which should demonstrate a revision of current CSR models. The strategic focus shifts from shareholder primacy toward the satisfaction of stakeholders (Mayer, 2012; Stout, 2012), which respectively reshapes the perception of company accountability and leads to a transition towards integrated reporting. The company's success viewed through the lens of market and financial performance and maximizing shareholder value is replaced with sustainable development approach balancing financial, social and environmental performance.

On the operational level, CSR is an additional aspect to be covered by the CG structure, represented mostly by the board monitoring it, and is to be incorporated in company strategy as a result of the notion that business has to respond to changing societal expectations. The CSR-CG integration model leads to a reorientation of the board's work and tasks. The convergence between CG and CSR is mostly driven by the view that the board of directors fulfils fiduciary duties and is responsible to stakeholders for the company's performance.

\section{Conclusions}

Understanding the mechanisms that explain why and how companies are driven to engage in CSR remains one of the most challenging topics in management studies. The literature attempts to track the patterns of mutual relations between CG and CSR and searches for companies' characteristics that drive their decision on engagement with CSR. Some authors argue that setting a framework for responsible business supported by relevant policies is an important part of $\mathrm{CG}$ and that good governance is a foundational requirement for CSR (Elkington 2006; Jamali et al., 2008). Ho (2005) identifies CSR as one of five dimensions of good $\mathrm{CG}$ and additionally proves that conformance to the latter is positively correlated to competitiveness. Other authors go further with this assumption and suggest that companies with more effective governance are more likely to engage in CSR in order to reduce conflict between investing and noninvesting stakeholders and generate higher firm value for shareholders (Harjoto \& Jo 2011; Jo \& Harjoto 2011).
While this finding is challenged in some studies (Bondy et al., 2008; Barnea \& Rubin, 2010; Dam \& Scholtens, 2012), companies that score better in CG ratings tend to declare higher social and environmental awareness and engage in social and environmental activities, as well as prove to be more ethical.

The objective of the article was to trace modes of CSR and $\mathrm{CG}$ integration at the company level based on a review of the existing literature. To pursue this goal, this paper relates in a great sense to previous works suggesting the need to include social responsibility in the formula of $\mathrm{CG}$ and to address the deficiencies of short-term shareholderoriented thinking. The CG of today is viewed as more complex to ensure that the checks and balances address the issues raised by stakeholders and respond to the social and environmental impact of business (Verdeyen et al., 2004; Beltratti, 2005). Addressing the strategic role of CSR in companies, the paper conceptualises the integration between $\mathrm{CSR} / \mathrm{CG}$ in a four-mode model. In our framework, we distinguish the modes as antagonism, instrumental legitimacy, instrumental strategy, and integration and internalisation. The CSR-CG integration framework outlines actions undertaken by a company in the selected modes with respect to strategic focus, supervision, accountability, performance measures, and reporting.

Different modes of CSR/CG lead to the emergence of various governance and evaluation structures. These modes represent also the evolution of the conceptual framework used to understand business and societal relations. Specifically, the dominance of the agency view revealed in the antagonism and separation mode redevelops into enlightened shareholder value to explain instrumental legitimacy and evolves towards the stakeholder-agency view in the integration and internalisation mode.

The proposed framework illustrates that companies differ in their understanding of their purpose of operation and the definition of stakeholders they are accountable to. The decision about the scope of business responsibilities in terms of its impact on society and the environment remains a company's fundamental choice. It cascades throughout the company in the form of governance structure, reporting practice, performance evaluation, and further organisational processes. Our model mirrors not only the adopted conceptual frameworks for hypotheses building in empirical studies but reveals also prevalent views on the CSR-CG relationship at the company level. As long as we observe the reorientation in theories of CSR and CG towards a more integrated approach, the empirical evidence fails to provide strong support for its adoption in practice. Specifically, our analysis suggests the ubiquity of the approach in which CSR and CG are antagonistic or CSR supports the realisation of the firm's primary goal, which is the maximisation of shareholder value. The review of empirical research suggests that the integration and internalisation modes fail to mirror the business practice of the links between CSR and CG. Thus, we argue that the claim of shareholder-stakeholder strategic integration appears to be, at least for now, an idealistic concept in management.

While our study is limited to the most cited articles on the CSR-CG relationship, it offers a synthesis and an in- 
depth analysis of the existing literature and formulates theoretical implications. Our findings may be useful as a springboard for further research, which should address the seminal questions of determinants that encourage and motivate companies to engage in the integration of shareholder-stakeholder expectations at the strategic level. Such determinants may refer to internal firm characteristics (ownership structure, board composition and work, incentive mechanisms, corporate culture) as well as the environmental context (institutions, regulation, dominant norms, and values). The identification of these determinants would be of great value for both research and practice because it would enhance our understanding on organisational responses to changes in the environment, here mostly dynamically emerging stakeholder expectations. This could also serve as a practical tool for managing CSR both at the company and national levels. Failure to identify these determinants may result in the failure to understand the factors that motivate and drive CSR strategic adoption by companies. This may impair the development of companies that appears to have stopped at the instrumental legitimacy and strategic mode. Consequently, the lack of understanding of the logic of organisational response may be detrimental to the shift toward sustainable business and society and hinder the dialogue to solve the most critical problems of society and the environment.

\section{References}

Aguilera, R., Williams, C., Conley, J., \& Rupp, D. (2006). Corporate governance and social responsibility: A comparative analysis of the UK and the US. Corporate Governance - An International Review, 14(3), 147-158. https://doi.org/10.1111/j.1467-8683.2006.00495.x

Aguilera, R., Rupp, D., Williams, C., \& Ganapathi, J. (2007). Putting the S back in corporate social responsibility: A multi-level theory of social change in organizations. Academy of Management Review, 32(3), 836-863. https://doi.org/10.5465/amr.2007.25275678

Aguinis, H., \& Glavas, A. (2013). Embedded versus peripheral corporate social responsibility: Psychological foundations. Industrial and Organizational Psychology - Perspectives on Science and Practice, 3, 314-332. https://doi.org/10.1111/iops.12059

Ammann, M., Oesch, D., \& Schmid, M. M. (2011). Corporate governance and firm value: International evidence. Journal of Empirical Finance, 18, 36-55. https://doi.org/10.1016/j.jempfin.2010.10.003

Arenas, D., Lozano, J. M., \& Albareda, L. (2009). The role of NGOs in CSR: Mutual perceptions among stakeholders. Journal of Business Ethics, 88(1), 175-197. https://doi.org/10.1007/s10551-009-0109-x

Arora, P., \& Dharwadkar, R. (2011). Corporate governance and corporate social responsibility (CSR): The moderating roles of attainment discrepancy and organization slack, Corporate Governance - An International Review, 19(2), 136-152. https://doi.org/10.1111/j.1467-8683.2010.00843.x

Ayuso, S., \& Argandona, A. (2007). Responsible corporate governance: Towards a stakeholder board of directors? "la Caixa" Chair of Corporate Social Responsibility and Corporate Governance, Working Paper no. 701, IESE Business School, University of Navarra.

Barnea, A., \& Rubin, A. (2010). Corporate social responsibility as a conflict between shareholders. Journal of Business Ethics, 97(1), 71-86. https://doi.org/10.1007/s10551-010-0496-z

Baumgartner, R. (2013). Managing corporate sustainability and CSR: A conceptual framework combining values, strategies and instruments contributing to sustainable development. Corporate Social Responsibility and Environmental Management, 21(5), 258-271. https://doi.org/10.1002/csr.1336

Beltratti, A. (2005). The complementarity between corporate governance and corporate social responsibility. The Geneva Papers, 30, 373-386. https://doi.org/10.1057/palgrave.gpp.2510035

Bhimani, A., \& Soonawalla, K. (2005). From conformance to performance: The corporate responsibilities continuum. Journal of Accounting and Public Policy, 24(3), 165-174. https://doi.org/10.1016/j. jaccpubpol.2005.03.001

Bocken, N. M. P., Short, S. W., Rana, P., \& Evans, S. (2014). A literature and practice review to develop sustainable business model archetypes. Journal of Cleaner Production, 65, 42-56. https://doi.org/10.1016/j.jclepro.2013.11.039

Bondy, K., Matten, D., \& Moon, J. (2008). Multinational corporation codes of conduct: Governance tools for corporate social responsibility? Corporate Governance: An International Review, 16(4), 294-311. https://doi.org/10.1111/j.1467-8683.2008.00694.x

Boons, F. M., \& Ludeke-Freund, F. (2013). Business models for sustainable innovation: State-of-the art and steps towards a research agenda. Journal of Cleaner Production, 45, 9-19. https://doi.org/10.1016/j.jc lepro.2012.07.007

Brammer, S., Jackson, G., \& Matten, D. (2012). Corporate social responsibility and institutional theory: new perspectives on private governance. Socio-Economic Review, 10(1), 3-28. https://doi.org/10.1093/ser/mwr030 
Maria Aluchna, Maria Roszkowska-Menkes. Integrating Corporate Social Responsibility and Corporate Governance...

Brown, J., \& Dillard, J. (2014). Integrated reporting: On the need for broadening out and opening up. Accounting, Auditing \& Accountability Journal, 27(7), 1120-1156. https://doi.org/10.1108/aaaj-04-2013-1313

Carroll, A. (1979). Three-dimensional conceptual model of corporate performance. Academy of Management Review, 44, 497-505. https://doi.org/10.2307/257850

Carroll, A. (1999). Corporate social responsibility: Evolution of a definitional construct. Business and Society, 38(3), 268-295. https://doi.org/10.1177/000765039903800303

Charan, R., \& Freeman, R. (1980). Planning for the business environment of the 1980s. Journal of Business Strategy, 12, 9-19. https://doi.org/10.1108/eb038895

Chih, H. L., Shen, C. H., \& Kang, F. C. (2008). Corporate social responsibility, investor protection, and earnings management: Some international evidence. Journal of Business Ethics, 79(1-2), 179-198. https://doi.org/10. 1007/s10551-007-9383-7

Clarke, T. (2014). Dangerous frontiers in corporate governance, Journal of Management and Organization, 20(3), 268-286. https://doi.org/10.1017/jmo.2014.37

Coffey, B. S., \& Wang, J. (1998). Board diversity and managerial control as predictors of corporate social performance. Journal of Business Ethics, 17(14), 1595-1603. https://doi.org/10.1007/s10551-017-3760-7

COM (2011). 681, Communication from the Commission to the European Parliament, the Council, the European Economic and Social Committee and the Committee of the Regions: A renewed EU strategy 2011-14 for Corporate Social Responsibility, Brussels. Available from internet: http://bit.ly/1yAbfQZ

Crane, A., Palazzo, G., Spence, L. J., \& Matten, D. (2014). Contesting the value of "creating shared value". California Management Review, 56(2), 130-153. https://doi.org/10.1525/cmr.2014.56.2.130

Dahlander, L., \& Gann, D. M. (2010). How open is innovation? Research Policy, 39(6), 699-709. https://doi.org/10.1016/j.respol.2010.01.013

Dahlsrud, A. (2008). How corporate social responsibility is defined: an analysis of 37 definitions. Corporate Social Responsibility and Environmental Management, 15, 1-13. https://doi.org/10.1002/csr.132

Dam, L., \& Scholtens, B. (2012). Does ownership type matter for corporate social responsibility? Corporate Governance: An International Review, 20(3), 233-252. https://doi.org/10.1111/j.1467-8683.2011.00907.x

Donaldson, T., \& Preston, L. (1995). The stakeholder theory of the corporation: Concepts, evidence, and implications. Academy of Management Review, 20(1), 65-91. https://doi.org/10.5465/amr.1995.9503271992

Dore, R. (2008). Financialization of the global economy. Industrial and Corporate Change, 17(6), 1079-1112. https://doi.org/10.1093/icc/dtn041

Dyllick, T., \& Muff, K. (2016). Clarifying the meaning of sustainable business. Organization \& Environment, 29(2), 156-174. https://doi.org/10.1177/1086026615575176

Elkington J. (1997). Cannibals with Forks: The Triple Bottom Line of 21st Century Business. New Society Publishers. https://doi.org/10.1002/tqem.3310080106

Elkington, J. (2006). Governance for sustainability. Corporate Governance: An International Review, 14(6), 522-529. https://doi.org/10.1111/j.1467-8683.2006.00527.x

Fassin, Y. (2012). Stakeholder management, reciprocity and stakeholder responsibility. Journal of Business Ethics, 109(1), 83-96. https://doi.org/10.1007/s10551-012-1381-8

Fisher-Vanden, K., \& Thorburnb, K. S. (2011). Voluntary corporate environmental initiatives and shareholder wealth. Journal of Environmental Economics and Management, 62(3), 430-445. https://doi.org/10.1016/j.je em.2011.04.003.

Fleming, P., \& Jones, M. (2013). The End of Corporate Social Responsibility. Crisis and Critique, Sage Publications.

Freeman, I., \& Hasnaoui (2011). The meaning of corporate social responsibility: The vision of four nations. Journal of Business Ethics, 100(3), 419-443. https://doi.org/10.1007/s10551-010-0688-6

Freeman, R. E., \& McVea, J. (2001). A stakeholder approach to strategic management, SSRN, Available at: http://ssrn.com/abstract=263511 [Accessed May 30, 2014]. https://doi.org/10.2139/ssrn.263511

Freeman, R. E. (1999). Divergent stakeholder theory. Academy of Management Review, 24(2), $233-236$. https://doi.org/10.5465/amr.1999.1893932

Freeman, R. E. (2010). Strategic Management - A Stakeholder Approach, New York: Cambridge University Press. https://doi.org/10.1017/CBO9781139192675 
Freeman, R. E., Wicks, A., \& Parmar, B. (2004). Stakeholder theory an "the corporate objective" revisited. Organisation Science, 15(3),364-369. https://doi.org/10.1287/orsc.1040.0066

Friedman, M. (1970). The social responsibility of business is to increase its profits. The New York Times Magazine, September 13 .

Frynas, J. G. (2008). Corporate social responsibility and international development: Critical assessment. Corporate Governance - An International Review, 16(4), 274-281. https://doi.org/10.1111/j.1467-8683.2008.00691.x

Frynas, J. G., \& Yamahaki, C. (2016). Corporate social responsibility: review and roadmap of theoretical perspectives. Business Ethics: A European Review, 25(3), 258-285. https://doi.org/10.1111/beer.12115

G20/ OECD. (2015). Principles of Corporate Governance, Available at: http://www.oecd.org/daf/ca/CorporateGovernance-Principles-ENG.pdf. https://doi.org/10.1002/bl.30032

Galema, R., Plantinga, A., \& Scholtens, B. (2008). The stocks at stake: Return and risk in socially responsible investment. Journal of Banking \& Finance, 32(12), 2646-2654. https://doi.org/10.1016/j.jbankfin.2008.06.002

Garcia-Sanchez, I. M., Rodriguez-Ariza, L., \& Frias-Aceituno, J. V. (2013). The cultural system and integrated reporting. International Business Review, 22(5), 828-838. https://doi.org/10.1016/j.ibusrev.2013.01.007

Gordon, J. M. (2007). The rise of independent directors in the United States, 1950-2005: Of shareholder value and stock market prices, Stanford Law Review, 59(6), 1465-1568. https://doi.org/10.2139/ssrn.928100 https://doi.org/10. 2139/ssrn.928100

Graves, S. B., \& Waddock, S. A. (1994). Institutional owners and corporate social performance. Academy of Management Journal, 37(4), 1034-1046. https://doi.org/10.2307/256611

Guay, T., Doh, J. P., \& Sinclair, G. (2004). Non-governmental organizations, shareholder activism, and socially responsible investments: Ethical, strategic, and governance implications. Journal of Business Ethics, 52(1), 125139. https://doi.org/10.1023/b:busi.0000033112.11461.69

Hardjono, T. (2001). The social dimensions of business excellence. Corporate Environmental Strategy, 83,223-233. https://doi.org/10.1016/s1066-7938(01)00125-7

Harjoto, M., \& Jo, H. (2011). Corporate governance and CSR nexus. Journal of Business Ethics, 100(1), $45-67$. https://doi.org/10.1007/s10551-011-0772-6

Harjoto, M., \& Jo, H. (2012). The causal effect of corporate governance on corporate social responsibility. Journal of Business Ethics, 106(1), 53-72. https://doi.org/10.1007/s10551-011-1052-1

Heath, J., \& Norman, W. (2004). Stakeholder theory, corporate governance and public management: What can the history of state-run enterprises teach us in the post-Enron era? Journal of Business Ethics, 53(3), $247-265$. https://doi.org/10.1023/b:busi.0000039418.75103.ed

Huang, C. H. (2010). Corporate governance, corporate social responsibility and corporate performance. Journal of Management and Organization, 16, 641-655. https://doi.org/10.1017/s1833367200001784

Husted, B., \& de Salazar, J. (2006). Taking Friedman seriously: Maximizing profits and social performance. Journal of Management Studies, 43(1), 75-91. https://doi.org/10.1111/j.1467-6486.2006.00583.x

Jackson, G., \& Apostolakou, A. (2009). Corporate social responsibility in Western Europe: An institutional mirror or substitute? Journal of Business Ethics, 94(3), 371-394. https://doi.org/10.1007/s10551-009-0269-8

Jamali, D., Safieddine, A., \& Rabbath, M. (2008). Corporate governance and corporate social responsibility synergies and interrelationships. Corporate Governance: An International Review, 16(5), 443-459. https://doi.org/10.1 111/j.1467-8683.2008.00702.x

Jo, H., \& Harjoto, M. (2011). Corporate governance and firm value: The impact of corporate social responsibility. Journal of Business Ethics, 103(3), 351-383. https://doi.org/10.1007/s10551-011-0869-y

Johnson, R. A., \& Greening, D. W. (1999). The effects of corporate governance and institutional ownership types on corporate social performance. Academy of Management Journal, 42(5), 564-576. https://doi.org/10.2307/256977

Juscius, V., \& Jonikas, D. 2013. Integration of CSR into value creation chain: Conceptual framework. Inzinerine Ekonomika-Engineering Economics, 24(1), 63-70. https://doi.org/10.5755/j01.ee.24.1.2016

Kang, N., \& Moon, J. (2012). Institutional complementarity between corporate governance and Corporate Social Responsibility: a comparative institutional analysis of three capitalisms. Socio-Economic Review, 10(1), 85-108. https://doi.org/10.1093/ser/mwr025

Karnani, A. (2011). Doing well by doing good: The grand illusion. California Management Review, 53(2), 69-86. https://doi.org/10.1525/cmr.2011.53.2.69 
Maria Aluchna, Maria Roszkowska-Menkes. Integrating Corporate Social Responsibility and Corporate Governance...

Khan, A., Muttakin, M., \& Siddiqui, J. (2013). Corporate governance and corporate social responsibility: Evidence from an emerging economy, Journal of Business Ethics, 114(2), 207-223. https://doi.org/10.1007/s10551-0121336-0 https://doi.org/10.1007/s10551-012-1336-0

Kolk, A., \& Pinkse, J. (2010). The integration of corporate governance in corporate social responsibility disclosure. Corporate Social Responsibility and Environmental Management, 17(1), 15-26. https://doi.org/10.1002/csr.196

Krippner, G. (2005). The financialization of the American economy. Socio-Economic Review, 3(2), 173-208. https://doi.org/10.1093/ser/mwi008

Kurland, N. (2017). Accountability and the public benefit corporation, Business Horizons, 60, 519-528. https://doi.org/10.1016/j.bushor.2017.03.009

Lantos, G. (2002). The ethicality of altruistic corporate social responsibility. Journal of Consumer Marketing, 19(3), 205-232. https://doi.org/10.1108/07363760210426049

Lattemann, C., Fetscherin, M., Alon, I., Li, S., \& Schneider, A. M. (2009). CSR communication intensity in Chinese and Indian multinational companies. Corporate Governance - An International Review, 17(4), 426-442. https://doi.org/10.1111/j.1467-8683.2009.00758.x

Larcker, D., \& Tayan, B. (2013). Corporate Governance Matters, Pearson, Upper Saddle River.

Li, W., \& Zhang, R. (2010). Corporate social responsibility, ownership structure, and political interference: Evidence from China. Journal of Banking \& Finance, 96(4), 631-645. https://doi.org/10.1007/s10551-010-0488-z

Levy, D. L., Szejnwald-Brown, H., \& de Jong, M. (2010). The contested politics of corporate governance: The case of the Global Reporting Initiative. Business \& Society, 49(1), 88-115. https://doi.org/10.1177/0007650309345420

Lo, S. F., \& Sheu, H. J. (2007). Is corporate sustainability a value-increasing strategy for business? Corporate Governance - An International Review, 15(2), 345-358. https://doi.org/10.1111/j.1467-8683.2007.00565.x

Lockett, A., Moon, J., \& Visser, W. (2006). Corporate social responsibility in management research: focus, nature, salience and sources of influence, Journal of Management Studies, 43(1), 115-136. https://doi.org/10.1 111/j.1467-6486.2006.00585.x

Matuleviciene, M., \& Stravinskiene, J. (2016). How to Develop Key Stakeholders Trust in Terms of Corporate Reputation. Inzinerine Ekonomika-Engineering Economics, 27(4), 472-478. https://doi.org/10.5755/j01. ee.27.4.13987

Mayer, C. (2012). Firm Commitment, Oxford University Press.

McWilliams, A., Siegel, D., \& Wright, P. (2006). Corporate social responsibility: Strategic implications. Journal of Management Studies, 43(1),1-18. https://doi.org/10.1111/j.1467-6486.2006.00580.x

Meyer, J., Rowan, B. (1977). Institutionalized organizations: formal structure as myth and ceremony. American Journal of Sociology, 83, 340-363. https://doi.org/10.1086/226550

Milton, S. (2010). Some observations on CSR and strategic management. Budapest Management Review, 41(2), 59-67.

Moon, J., Orlitzky, M., \& Whelan, G. eds. (2010). Corporate Governance and Business Ethics, Edward Elgar Publishing, Northampton. https://doi.org/10.4337/9781785362163

Perrault, E., \& McHugh, P. (2015). Toward a life cycle theory of board evolution: Considering firm legitimacy, Journal of Management \& Organization, 21(5), 627-649. https://doi.org/10.1017/jmo.2014.92

Petrokaite, K., \& Stravinskiene, J. (2013). Corporate reputation management decisions: Customer's perspective, Inzinerine Ekonomika-Engineering Economics, 24(5), 496-506. https://doi.org/10.5755/j01.ee.24.5.3920

Porter, M., \& Kramer, M. (2006). Strategy and society: The link between competitive advantage and corporate social responsibility, Harvard Business Review, 89 (December).

Prado-Lorenzo, J. M., Gallego-Alvarez, I., \& Garcia-Sanchez, I. M. (2009). Stakeholder engagement and corporate social responsibility reporting: The ownership structure effect. Corporate Social Responsibility and Environmental Management, 16(2), 94-107. https://doi.org/10.1002/csr.189

Prior, D., Surroca, J., \& Tribo, J. (2008). Are socially responsible managers really ethical? Exploring the relationship between earnings management and corporate social responsibility. Corporate Governance: An International Review, 16(3), 160-177. https://doi.org/10.1111/j.1467-8683.2008.00678.x

Rao, K., \& Tilt, C. (2016). Board composition and corporate social responsibility: The role of diversity, gender, strategy and decision making. Journal of Business Ethics, 138, 327-347. https://doi.org/10.1007/s10551-0152613-5 
Renneboog, L., Ter Horst, J., \& Zhang, C. (2008). Socially responsible investments: Institutional aspects, performance, and investor behavior. Journal of Banking and Finance, 32(9), 1723-1742. https://doi.org/10.10 16/j.jbankfin.2007.12.039

Sacconi, L. (2006). A social contract account for CSR as an extended model of corporate governance (I): Rational bargaining and justification. Journal of Business Ethics, 68(3), 259-281. https://doi.org/10.1007/s10551-0069014-8

Salciuviene, L., Hopeniene, R., \& Dovaliene, A. (2016). perceived corporate social responsibility and its implementation in practice: The case of Lithuanian small and medium-sized enterprises, Inzinerine EkonomikaEngineering Economics, 27(4), 479-490. https://doi.org/10.5755/j01.ee.27.4.14713

Shamir, R. (2004). Between self-regulation and the Alien Tort Claims Act: On the contested concept of corporate social responsibility. Law \& Society Review, 38(4), 635-664. https://doi.org/10.4324/9781351126816-6

Shleifer, A., \& Vishny, R. (1997). A survey of corporate governance, Journal of Finance, 52, 737-783. https://doi.org/10.1111/j.1540-6261.1997.tb04820.x

Stout, L. (2012). The Shareholder Value Myth: How Putting Shareholders First Harms Investors, Corporations and the Public, Berrett-Kohler Publishing, San Francisco.

Stubbs, W., \& Higgins, C. (2014). Integrated reporting and internal mechanisms of change. Accounting, Auditing \& Accountability Journal, 27(7), 1068-1089. https://doi.org/10.1108/aaaj-03-2013-1279

Tranfield, D., Denyer, D., \& Smart, P. (2003). Towards a methodology for developing evidence-informed management knowledge by means of systematic review. British Journal of Management, 14(3), $207-222$. https://doi.org/10.11 11/1467-8551.00375

Tricker, B. (2012). Corporate Governance. Principles, Policies and Practices, Oxford University Press.

Upward, A., \& Jones, P. (2015). An ontology for strongly sustainable business models. Organization \& Environment, 29(1), 97-123. https://doi.org/10.1177/1086026615592933

Valackiene, A., \& Miceviciene, D. (2011). Methodological framework analysing a social phenomenon: Stakeholder orientation implementing balanced corporate social responsibility, Inzinerine Ekonomika-Engineering Economics, 22(3), 300-308. https://doi.org/10.5755/j01.ee.22.3.520

van Marrewijk, M. (2003). Concepts and definitions of CSR and corporate sustainability: Between agency and communion. Journal of Business Ethics, Volume 2 of the series Advances in Business Ethics Research, 641-655. https://doi.org/10.1007/978-94-007-4126-3_32

Verdeyen, V., Put, J., \& van Buggenhout, B. (2004). A social stakeholder model. International Journal of Social Welfare, 13(4), 325-331. https://doi.org/10.1111/j.1468-2397.2004.00328.x

Vermalen, T. (2009). Maximizing shareholder value. An ethical responsibility? in Smith, C. \& Lenssen, G. (eds.), Mainstreaming Corporate Responsibility, Chichester, Wiley, 206-218.

Visser, W. (2012). The Age of Responsibility: CSR 2.0 and the New DNA of Business. London: Willey.

Vogel, D. (2005). Is there market for virtue? The business case for corporate social responsibility. California Management Review, 47(4), 19-45. https://doi.org/10.2307/41166315

Whelan, G. (2012). The political perspective of corporate social responsibility: A critical research agenda. Business Ethics Quarterly, 22(4), 709-737. https://doi.org/10.5840/beq201222445

Wood, D. (1991). Corporate social performance revisited. Academy of Management Review, 16(4), 691-718. https://doi.org/10.5465/amr.1991.4279616

Zahra, S. A., Oviatt, B. M., \& Minyard, K. (1993). Effect of Corporate Ownership and Board Structure on Corporate Social Responsibility and Financial Performance. Academy of Management Best Paper Proceedings, 993(1), 336-340. https://doi.org/10.5465/ambpp.1993.10317088

Zingales, L. (2008). Corporate governance, in: Durlauf, S., \& Blume, L., (eds.) The New Palgrave Dictionary of Economics. Second Edition, Palgrave Macmillan, 1145-1152. https://doi.org/10.1057/978-1-349-95121-5_2416-1

The article has been reviewed.

Received in January 2017; accepted in June 2019. 